\title{
TO SIR EDWARD APPLETON
}

\author{
On hearing his Presidential Address to the British Association, 1953
}

Within the hush'd and crowded hall, now gay With learning's silken panoplied array, We sit enrapt; companion'd, warm, secure In a familiar world, serene, demure; Our minds elsewhere, above the veil of night Borne on imagination's thrusting flight Through the unending, roofless vaults of space Where galaxies pursue their timeless race In distant majesty; about them spread A seeming frozen silence, deathless, dead.
Did we possess your magic, we might hear The voiceless ether murm'ring low and clear A myriad soft whispers, mystic tone Of outer worlds, the known and yet unknown. How wise the mind that thus can apprehend A universe too vast to have an end, The ear its ghostly note detect, the hand A new strange music of the spheres command.

\section{NEWS and VIEWS}

British Association :

President for 1954 : Dr. E. D. Adrian, O.M., F.R.S.

DR. E. D. Adrian has been elected president of the British Association for 1954 and will therefore preside over next year's annual meeting at Oxford. Dr. Adrian has been president of the Royal Society since 1950. His work, which has had such a profound effect on the biological sciences, was reviewed in Nature on his election as president of the Royal Society (Nature, 166, 978; 1950). Much of his scientific research was carried out while he was Foulerton professor of the Royal Society during 1929-37 and later professor of physiology in the University of Cambridge during 1937-51. He holds the Baly Medal of the Royal College of Physicians, a Royal and the Copley Medals of the Royal Society and the Gold Medal of the Royal Society of Medicine. In 1932 he was awarded the Nobel Prize for Medicine, and in 1942 he received the Order of Merit. Since 1951, Dr. Adrian has been Master of Trinity College, Cambridge.

Downe House

Downe House, Kent, the national memorial ${ }^{-}$to Charles Darwin, where for forty years Darwin lived and where he wrote his "Origin of Species", has been transferred from the custody of the British Association to that of the Royal College of Surgeons.

\section{Technology and Professional Work}

Some points raised by Lieut-Colonel S. M. K. Mallick's address, "Medicine-a Technology or a Profession", at the plenary session on August 24 of the First World Conference on Medical Education are of interest in the wider context of current discussion in Great Britain on higher technological education generally. Accepting the definition of a profession as implying an occupation in which one professes to be skilled and which one adopts as a means of living, Col. Mallick thought that there are still good reasons for restricting the word 'profession' to the three vocations of divinity, law and medicine. He defined technology as a systematized or scientific study of the practical or industrial arts, while medicine he claimed is a specialized knowledge the practice of which is concerned with disease and the advancement of health. Despite this rather controversial restriction of the term 'profession' and his failure to probe deeply enough into the meaning of technology, which he does not distinguish at all clearly from a technique, Col. Mallick's concern that through the mass-production of immature specialists, aided by socialization, the profession may be converted into a technology and the medical man become merely a high-class technician, has implications for the planning of higher technological education and especially for those who insist on the importance of an adequate basis of general education. The danger in medicine is that the specialized studies which are so readily encouraged by current tendencies will swamp the basic general education that a university discipline, such as medical education, is calculated to impart. A system which is more than vocational training must have a relevance to life in general, and though technical education is an indispensable foundation, education in the sense of the development of the power to form judgments becomes possible only after techniques have been mastered. Col. Mallick believes that the danger in medicine would be averted by the revival of the general physician and the general surgeon on better-organized lines, and by recognizing the difference between profession and technology and re-establishing the pre-eminence of the professional aspect and tradition.

\section{Science and Productivity in Britain}

IN a debate on science and productivity in the House of Commons on July 20, the Parliamentary Secretary to the House of Commons, Mr. Hugh Molson, referring to the recommendation in the sixth report of the Advisory Council for Scientific Policy regarding the increased use of development contracts, said that the Ministry of Fuel and Power has already granted contracts for developing gas turbines run on peat and on coal, while several contracts have been granted for developing the large heat pump made for heating and cooling the Royal Festival Hall. Mr. Molson said that the Department of Scientific and Industrial Research is also exploring the practicability of development through the research associations, and referred to collaboration between the Road Research Laboratory, the British Road Tar Association and the North Thames Gas Board in the

* Registrar, University of Liverpool, and Joint Local Hon. Secretary of the British Association Meeting at Liverpool, 1953. 